\title{
Effect of a Thermogenic Supplementation on Post Aerobic Exercise Hemodynamic Responses in Healthy Young Men
}

\author{
Vilton Emanoel Lopes de Moura e Silva ${ }^{1}$, Valmir Oliveira Silvino ${ }^{2}$, Jefferson Fernando \\ Coelho Rodrigues Júnior ${ }^{3}$, Alyson Felipe da Costa Sena ${ }^{4}$, Carlos Eduardo Neves Amorim ${ }^{5}$, \\ Christian Emmanuel Torres Cabido ${ }^{6}$, Marcos Antônio Pereira dos Santos ${ }^{7}$
}

\begin{abstract}
Introduction: The use of food supplements with esthetic or performance-enhancing goals has been largely investigated. Thermogenics are supplements that increase energy expenditure through thermogenesis and are widely consumed by individuals seeking to improve body composition and exercise performance. Objective: To evaluate the effects of a commercially available thermogenic supplement on post-exercise blood pressure responses. Materials and Methods: Twenty-seven healthy young men participated in the study. Nine volunteers were assigned in the control group ( $21.67 \pm 1.87$ years), nine in the thermogenic group $(24.00 \pm 4.18$ years), and nine in the placebo group ( $23.67 \pm 3.04$ years). The volunteers performed a treadmill aerobic exercise session for 60 minutes at 60 to $85 \% \mathrm{HRmax}$ after the treatment protocol. The hemodynamic variables were measured at rest and during 60 minutes in the post-exercise recovery. The normality of the data was evaluated using the Shapiro-Wilk test. Baseline momentum and post-exercise recovery were analyzed using the two-way Anova test (group versus time factors), with Bonferroni post-hoc test. The level of statistical significance was set at $p$ $<0.05$. Results: The thermogenic supplement did not significantly compromise post-exercise hypotension when compared to the other groups. However, thermogenic supplementation increased the blood pressure in $>5 \mathrm{mmHg}$, which reportedly plays an important role in cardiovascular diseases. Conclusion: The use of the thermogenic Lipo 6 Black Ultra Concentre Nutrex ${ }^{\circledR}$ did not alter PEH in healthy youngsters. However, since an increase in the blood pressure was observed, this supplementation must be administered with caution. Keywords: Thermogenic. Running. Post-exercise hypotension.
\end{abstract}

\section{EFEITO DE UM SUPLEMENTO TERMOGÊNICO NA RESPOSTA HEMODINÂMICAS PÓS-EXERCÍCIO AERÓBIO EM HOMENS JOVENS SAUDÁVEIS}

\section{RESUMO}

Introdução: O uso de suplementos alimentares com objetivos estéticos ou de melhoria no desempenho tem sido amplamente investigado. Termogênicos são suplementos que aumentam o gasto de energia através da termogênese e são comumente consumidos por indivíduos que buscam melhorar a composição corporal e o desempenho no exercício. Objetivo: Avaliar os efeitos de um suplemento termogênico comercialmente disponível nas respostas da pressão arterial pós-exercício. Materiais e Métodos: Vinte e sete homens jovens saudáveis participaram do estudo. Nove voluntários foram designados no grupo controle $(21,67 \pm 1,87$ anos), nove no grupo termogênico $(24,00 \pm 4,18$ anos) e nove no grupo placebo $(23,67 \pm 3,04$ anos). Os voluntários realizaram uma sessão de exercício aeróbio na esteira por 60 minutos em 60-85\% da FCmax após o protocolo de tratamento. As variáveis hemodinâmicas foram avaliadas em repouso e durante 60 minutos após recuperação do exercício. A normalidade dos dados foi avaliada pelo teste de Shapiro-Wilk. $O$ momento basal e a recuperação pós-exercício foram analisados usando o teste Anova de duas vias (fatores grupo versus tempo), com o teste post-hoc de Bonferroni. O nível de significância estatística foi estabelecido em $p<0,05$. Resultados: 0 suplemento termogênico não comprometeu significativamente a hipotensão pós-exercício quando comparado aos outros grupos. No entanto, o suplemento termogênico aumentou a pressão arterial em $>5 \mathrm{mmHg}$, o que reportadamente pode desempenhar um papel importante em doenças cardiovasculares. Conclusão: $\mathrm{O}$ uso do termogênico Lipo 6 Black Ultra Concentre Nutrex ${ }^{\circledast}$ não alterou a HPE em homens jovens saudáveis. No entanto, como foi observado um aumento na pressão sanguínea, essa suplementação deve ser administrada com cautela.

Palavras-chave: Termogênico. Corrida. Hipotensão Pós-Exercício.

RECEBIDO EM: 21/12/2019

MODIFICAÇÕES SOLICITADAS EM: 26/2/2020

ACEITO EM: 26/3/2020

\footnotetext{
Department of Biophysics and Physiology, Nucleus of Study in Physiology Applied to Performance and Health (Nefads), Federal University of Piaui, PI, Brazil. http://lattes.cnpq.br/7924944035897429. https://orcid.org/0000-0002-5057-9554. vilton_emanoel@hotmail.com

Department of Biophysics and Physiology, Nucleus of Study in Physiology Applied to Performance and Health (Nefads), Federal University of Piaui, PI, Brazil. http://lattes.cnpq.br/4642858363901537. https://orcid.org/0000-0002-1992-5199. valmirsilvino@live.com

3 Physical Education Departament, Federal University of Maranhão - Pinheiro, MA, Brazil. http://lattes.cnpq.br/7115753214991670. https://orcid.org/00000001-7445-6156. jefferssonfernando@hotmail.com

${ }^{4}$ Physical Education Departament, Federal University of Maranhão - Sao Luís, MA, Brazil. http://lattes.cnpq.br/6571848561247862. https://orcid.org/00000001-8212-5779. afdcs94@hotmail.com

Physical Education Departament, Federal University of Maranhão - Pinheiro, MA, Brazil. http://lattes.cnpq.br/0109987596093206. https://orcid.org/00000002-4171-0688. amorimunifesp@gmail.com

${ }^{6}$ Physical Education Departament, Federal University of Maranhão - Sao Luís, MA, Brazil. http://lattes.cnpq.br/9102119601757395. https://orcid.org/00000002-4800-0128. christianemmanuel@gmail.com

Science and Health Post Graduation Department, Department of Biophysics and Physiology, Nucleus of Study in Physiology Applied to Performance and Health (Nefads), Federal University of Piaui, PI, Brazil. http://lattes.cnpq.br/8981790396061410. https://orcid.org/0000-0002-0755-6138. marcosedfisio@gmail.com
} 


\section{INTRODUCTION}

The use of dietary supplementation by physical activity practitioners has been widely employed to improve sports performance or for aesthetic purposes. Dietary supplements are concentrated sources of nutrients (vitamins, minerals, carbohydrates, fats, proteins, or plant extracts) intended to correct nutritional deficiencies or support specific physiological functions (CRIVELIN et al., 2018). It is estimated that approximately $20 \%$ of the American population consumes supplements for physical-enhancing purposes (DICKINSON et al., 2014).

A popular subset of these supplements, termed thermogenic, purportedly increases thermogenesis, promotes fat oxidation and improves physical performance (TINSLEY et al., 2017). Thermogenic supplements are ergogenic resources containing a combination of ingredients such as caffeine, green tea, rauwolscine, plant extracts, and fruits. They are used by many physical activity practitioners in order to keep the metabolism accelerated due to its thermogenic action. The increase in metabolism provided by this action promotes higher energy expenditure through fat oxidation (OUTLAW et al., 2014).

The sympathomimetic substances present in thermogenic compounds have been regarded as regulatory agents of adrenergic receptors $(\beta 1,2$, and 3 or $\alpha 1)$. In general, blood pressure increases through the activation of $\alpha 1$-adrenergic receptors. Similarly, $\beta 1$-adrenergic receptors increase heart rate. Additionally, ghrelin secretion in the stomach can alter appetite. $\beta 2$ adrenergic receptors binding produces smooth muscle relaxation and is associated with bronchodilation, and the activation of $\beta 3$ adrenergic receptors is associated with fatty acids oxidation and energy production (MUND; FRISHMAN, 2013).

A commercial thermogenic supplement that has been widely marketed is called Nutrex Lipo-6 Black Ultra Concentrated ${ }^{\circledR}$ (Nutrex Research, Inc., Oviedo, Fla.). It consists of caffeine, yohimbine and diiodine that act synergistically with synephrine. Although the mechanisms of this thermogenic supplement are understood, its effects on exercise-induced hemodynamics responses, such as post-exercise hypotension (PEH), have never been investigated. it has been reported that this supplement interacts with the central nervous system by stimulating vasoconstriction and elevating blood pressure, but its physiological role is not fully described (CAMPBELL et al., 2016). Recent studies with healthy individuals have shown that the use of thermogenic supplements could be associated with brain damage, gastrointestinal problems, and cardiovascular diseases (GOMES et al., 2014). In spite of the expressive adverse effects, there is no guarantee that thermogenic supplements were causative since they were reported in case studies.

It is well known that a single exercise session can promote a decrease in blood pressure levels immediately after it is over, and this effect remains for many hours. This clinical phenomenon is called post-exercise hypotension, in which the blood pressure values can be even smaller than those before the exercise session (RODRIGUES-JUNIOR et al., 2017). The mechanisms that affect post-exercise blood pressure are related to hemodynamic, humoral, and neural factors (ANUNCIAÇÃO; POLITO, 2011). Hemodynamic factors reduce cardiac output and peripheral vascular resistance, while neuro-humoral affect the afferent system, renin-angiotensin-aldosterone mechanism, and the antidiuretic hormone (BRUM et al., 2004). Efferent action of the autonomic sympathetic and parasympathetic nervous systems also contributes to this phenomenon (ADER et al., 2005).

Although several effects related to the use of thermogenic supplements have been reported, there are few studies regarding the influence of the use of these substances on PEH, which is an important non-drug tool for blood pressure lowering and control. Therefore, the present study aims to investigate the effect of an aerobic exercise session in the post-exercise blood pressure response in thermogenic supplement users.

\section{MATERIALS AND METHOD}

\section{Search Type}

This single-blind, placebo-controlled investigation was carried out with twenty-seven volunteers divided into three groups: Thermogenic + Exercise (TE) $(n=9,24.0 \pm 4.18$ years); Placebo + Exercise (PE) $(n=$ 9, $23.67 \pm 3.04$ years), and Control + Exercise (CE) ( $n$ $=9,21.67 \pm 1.87$ years). Volunteers participated in this study when the following inclusion criterion was fulfilled: subjects were athletes or recreational practioners of strength or aerobic training (at least five times a week, 30 minutes per session). Subjects with any known chronic-degenerative disease, smokers, and users of any anti-hypertension medicines or nutritional supplements were excluded from this investigation. A previous study about PEH and cardiac autonomic modulation was considered to calculate the minimum sample size (TEIXEIRA et al., 2011). Using a 
statistical power of 0.90 and an $\alpha$ error of 0.05 , a sample size of at least fifteen participants was found to be required for this study. The volunteers were recruited through electronic and printed advertisements on notice boards at a local university.

All volunteers were considered active according to the Ipaq test. Participants who had difficulties performing the aerobic exercise session were not used in this research. During the study, subjects were instructed to refrain from any other supplement. They were also asked to maintain their regular diet and training program. This study was approved by the ethics committee of the Universidade Federal do Piauí (Ufpi), Teresina, PI, Brazil under protocol 57089516.3.0000.5214. All participants signed the consent form according to resolution 196/96 of the National Health Council.

Subjects completed the experimental trial at the same time $(8-11 \mathrm{am})$. During the first stage, the volunteers were given the supplements. At the next stage, individuals were anthropometrically evaluated. Before aerobic exercise, volunteers remained at rest for 10 minutes when heart rate and blood pressure baseline measurements were assessed. Blood pressure measurements were taken before and during a post-exercise $60 \mathrm{~min}$ period of recovery, at intervals of 20 min between each measurement.

\section{EXPERIMENTAL PROCEDURES}

\section{Anthropometric measurements}

Body mass was assessed using a digital scale (Welmy, model W300, Brazil) with an accuracy of 0.02 grams and a capacity of $150 \mathrm{~kg}$. Height was measured using a portable stadiometer attached to the scale. Sample characterization is presented in Table 1 with values of mean and standard deviation of the volunteers' body characteristics.

Table 1 - Anthropometric variables of the participants

\begin{tabular}{cccc}
\hline & Control & Thermogenic & Placebo \\
\hline & \multicolumn{3}{c}{ Mean \pm SD } \\
Age (years) & $21.67 \pm 1.87$ & $24.00 \pm 4.17$ & $23.67 \pm 3.14$ \\
Weight (kg) & $74.54 \pm 13.48$ & $76.80 \pm 5.95$ & $70.17 \pm 10.57$ \\
Height (cm) & $176.45 \pm 5.24$ & $172.68 \pm 4.99$ & $173.33 \pm 7.60$ \\
BMI (kg/m $\left.\mathbf{m}^{2}\right)$ & $24.25 \pm 3.41$ & $25.76 \pm 2.22$ & $23.31 \pm 2.84$ \\
\hline
\end{tabular}

$\mathrm{SD}$, standard deviation; $\mathrm{BMI}$, body mass index; $\mathrm{n}=9$ each group. Source: Research data.

\section{Supplementation}

TE and PE volunteers ingested identical capsules with different content. Capsules intake started 20 hou$r s$ before exercise, one capsule being ingested every 10 hours, totalizing at the end 3 capsules per volunteer. The last capsule was ingested 1 hour before aerobic exercise. PE group ingested capsules composed

Figure 1 -Schematic view of the supplementation, exercise, and evaluation protocols

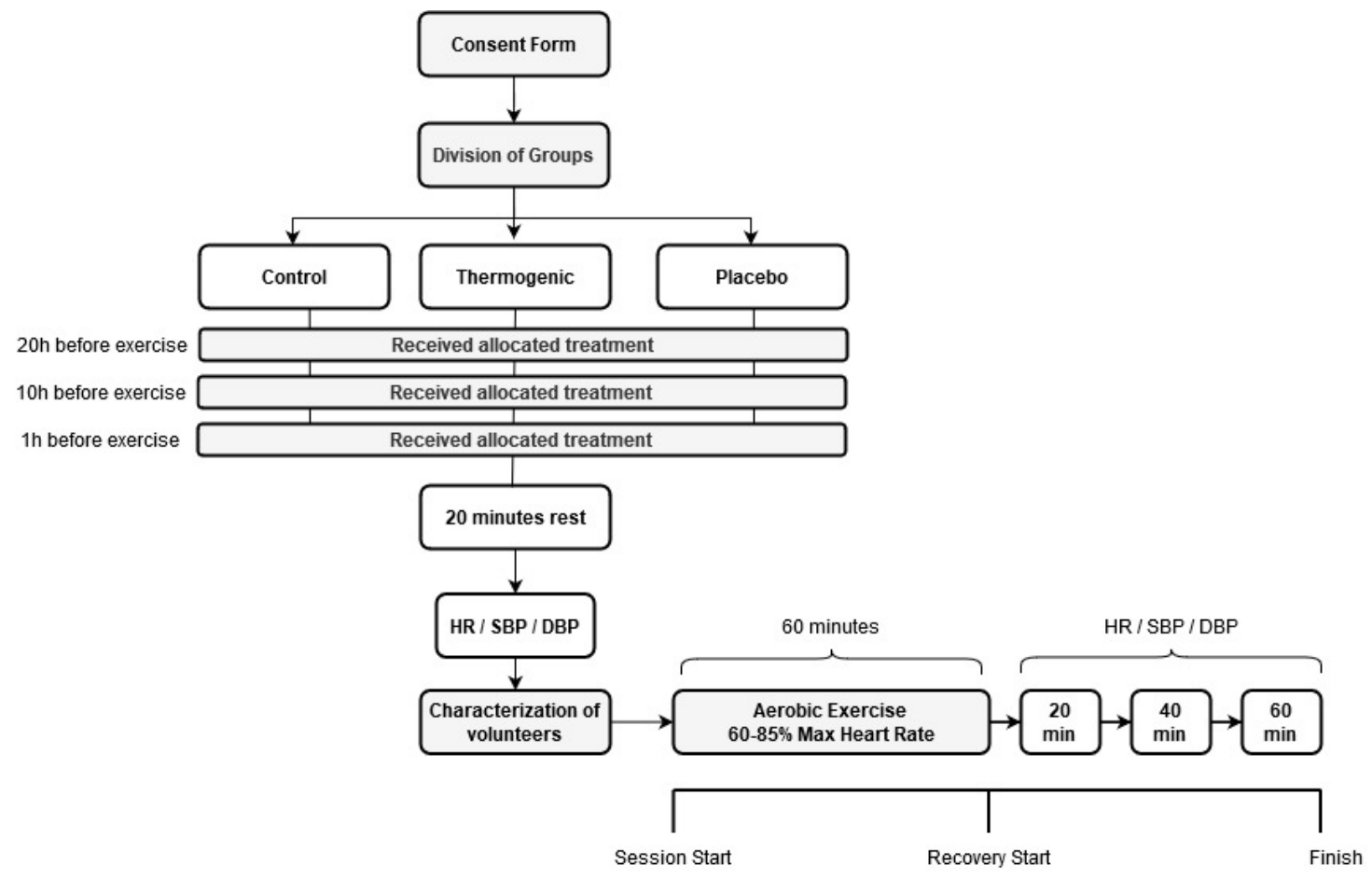

HR, heart rate; SBP, systolic blood pressure; DBP, diastolic blood pressure; min, minutes.

Source: The authors. 
of $12 \mathrm{mg}$ starch and TE group ingested capsules with Lipo 6 Black Ultra Concentre Nutrex ${ }^{\circledR}$. The capsules were identical in taste, smell, and color. The dosage of the termogenic supplementation was determined according to the manufacturer's recommendation. CE group did not intake any capsule.

Figure 2 - Thermogenic Supplement Label (Lipo 6 Black Ultra Concentre Nutrex ${ }^{\circledR}$ )

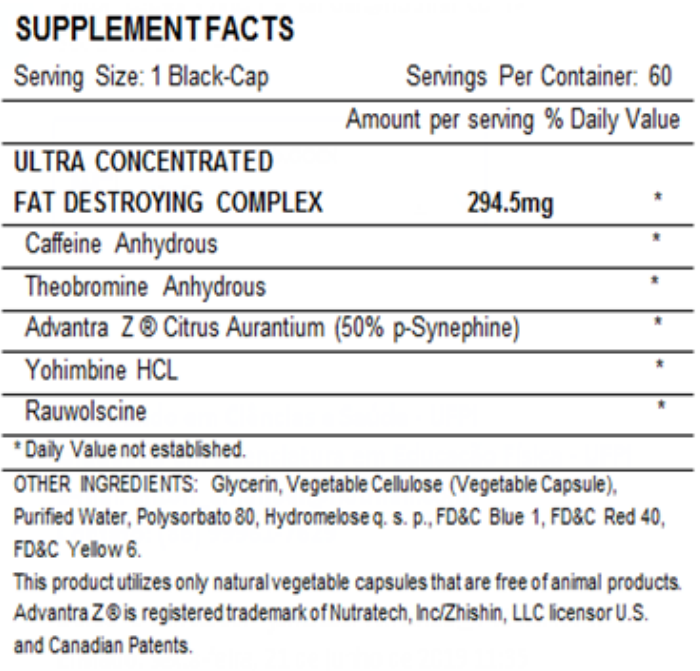

Source: Lipo 6 Black Ultra Concentre Nutrex ${ }^{\circledR}$ label.

\section{Physical exercise intervention}

The experimental aerobic exercise session was performed on a treadmill (ProAction BH fitness, Puerto del Carmen, Spain). Firstly, the subjects were instructed and submitted to a warm-up session on the treadmill for three minutes at low intensity $(<60 \%$ of age-predicted HRmax (220 - age in years)). Immediately thereafter, they started a gradual increase in speed every minute, during the first 5 min until they reached the prescribed intensity, determined through the equation (HRmax - HRresting) $x \%$ intensity) + HRresting, described by Karvonen, Kentala e Mustala (1957). They remained in this intensity range until the end of the workout (60 minutes).

\section{Hemodynamic variables}

Heart rate (HR) values were measured with the heart rate monitor V800 (Polar ${ }^{\circledR}$ Electro Oy, Kempele, Finland) before, at $0,20,40$, and 60 minutes during the 60-minute post-exercise recovery period. Systolic blood pressure (SBP) and diastolic blood pressure (DBP) were measured according to the recommendations of the Brazilian Guidelines on Hypertension (2010) using a BR A100 Plus oscillometric device (MICROLIFE BR3BTO-A/BR), previously validated by Cukson et al. (2002). During this period, the volunteers were asked to remain seated for at least $20 \mathrm{~min}$ in a quiet environment with a temperature between $24{ }^{\circ} \mathrm{C}$ and $27{ }^{\circ} \mathrm{C}$.

\section{Statistical analysis}

The data are presented as mean \pm standard deviation of the mean. The normality of the data was evaluated using the Shapiro-Wilk test. The groups and moments (before and at $0,20,40$, and 60 min post-exercise) were compared using the two-way Anova test, and post hoc tests with the Bonferroni correction were performed to analyse the interaction between the factors (group versus time). The significance level was set at $p<0.05$. Cohen's $d$ effect size (ES) was used to estimate the magnitude of the difference (COHEN, 1988). Values of $0-0.19,0.20-0.49,0.50-0.79$, and $>0.80$ were considered trivial, small, moderate, and large, respectively (LAKENS, 2013). The entire analysis was performed using SigmaPlot 11.0 software.

\section{RESULTS}

The participants were statistically similar in age, height, body mass and BMI. Hemodynamic behavior at rest did not show significant differences between groups (Table 2). No adverse events occurred as a result of supplementation. Most hemodynamic and safety variables were unaltered after the supplementation 
Table 2 - Hemodynamic responses before and during the 60 min of post-exercise recovery

\begin{tabular}{clccccc}
\hline & & Before & $\mathbf{0}$ & $\mathbf{2 0}$ & $\mathbf{4 0}$ & $\mathbf{6 0}$ \\
\hline \multirow{2}{*}{$\begin{array}{c}\text { HR } \\
(\mathbf{b p m})\end{array}$} & Control & $70.44 \pm 6.73$ & $125.67 \pm 13.04 * \&$ & $93.89 \pm 6.90 \# \&$ & $87.78 \pm 9.35 \# \&$ & $85.78 \pm 9.67 \# \&$ \\
\cline { 2 - 7 } & Placebo & $67.11 \pm 8.33$ & $132.44 \pm 10.65 * \&$ & $84.11 \pm 11.76 \# \&$ & $78.56 \pm 11.86 \# \&$ & $74.78 \pm 13.18 \# \&$ \\
\cline { 2 - 7 } & Thermogenics & $73.67 \pm 10.00$ & $121.44 \pm 9.15 * \&$ & $98.00 \pm 6.48 \# \&$ & $89.33 \pm 10.91 \# \&$ & $88.22 \pm 12.40 \# \&$ \\
\hline \multirow{2}{*}{$\begin{array}{c}\text { SBP } \\
(\mathbf{m m H g})\end{array}$} & Control & $120.78 \pm 12.09$ & $130.00 \pm 14.80 \beta$ & $115.44 \pm 12.02 \&$ & $110.89 \pm 10.03 \&$ & $112.44 \pm 9.23 \beta \&$ \\
\cline { 2 - 7 } & Placebo & $128.00 \pm 13.03$ & $144.78 \pm 16.55 \beta$ & $121.44 \pm 13.52 \&$ & $119.56 \pm 11.38 \&$ & $117.22 \pm 9.99 \beta \&$ \\
\cline { 2 - 7 } & Thermogenics & $126.67 \pm 12.39$ & $130.33 \pm 15.07 \beta$ & $121.56 \pm 14.90 \&$ & $119.78 \pm 15.87 \&$ & $118.22 \pm 10.76 \beta \&$ \\
\hline $\begin{array}{c}\text { DBP } \\
(\mathbf{m m H g})\end{array}$ & Control & $72.89 \pm 12.19$ & $75.33 \pm 17.13 \beta$ & $74.00 \pm 12.09 \&$ & $69.89 \pm 9.28 \&$ & $69.67 \pm 11.54 \beta \&$ \\
\cline { 2 - 7 } & Placebo & $69.89 \pm 6.68$ & $79.11 \pm 10.66 \beta$ & $71.56 \pm 10.22 \&$ & $68.67 \pm 11.18 \&$ & $71.00 \pm 8.92 \beta \&$ \\
\hline $\begin{array}{c}\text { MBP } \\
(\mathbf{m m H g})\end{array}$ & Thermogenics & $73.22 \pm 5.24$ & $80.00 \pm 11.08 \beta$ & $72.22 \pm 8.06 \&$ & $71.56 \pm 6.71 \&$ & $70.00 \pm 7.23 \beta \&$ \\
\cline { 2 - 7 } & Placebo & $88.85 \pm 11.61$ & $93.56 \pm 15.00$ & $87.81 \pm 10.97$ & $83.56 \pm 8.38$ & $83.93 \pm 9.91$ \\
\hline & Thermogenics & $89.26 \pm 9.28$ & $101.00 \pm 10.88 *$ & $88.07 \pm 9.77 \#$ & $85.63 \pm 10.46 \#$ & $86.41 \pm 8.20 \#$ \\
\hline
\end{tabular}

$\mathrm{HR}^{*}$ significant difference at 0 min compared to resting in placebo, control, and thermogenic groups ( $\left.\mathrm{p}<0.05\right)$; \# significant differences at 20-min post-exercise intervals (20, 40, and $60 \mathrm{~min}$ ) compared to $0 \mathrm{~min}$ in all groups $(p<0,05)$. \& significant difference for $0 \mathrm{~min}$ and 20 -min post-exercise intervals $(20,40$, and $60 \mathrm{~min})$ compared to rest. There was no goup $x$ time interaction for the SBP and DBP variables. However, there was a moment interaction. DBP $\beta$, SBP $\beta$ - significant difference at 0 min and 60 min compared to resting. \& significant difference at 20-min post-exercise intervals $(20,40$, and $60 \mathrm{~min}$ ) compared to $0 \mathrm{~min}$. MBP * significant difference for 0 min compared to resting in placebo; \# significant differences at 20 -min post-exercise intervals $(20,40$, and $60 \mathrm{~min})$ compared to $0 \mathrm{~min}$ in placebo and thermogenic groups.

Figure 3 - Behavior of the heart rate during the $60 \mathrm{~min}$ of post-exercise recovery. Data presented as means and standard deviation of the means

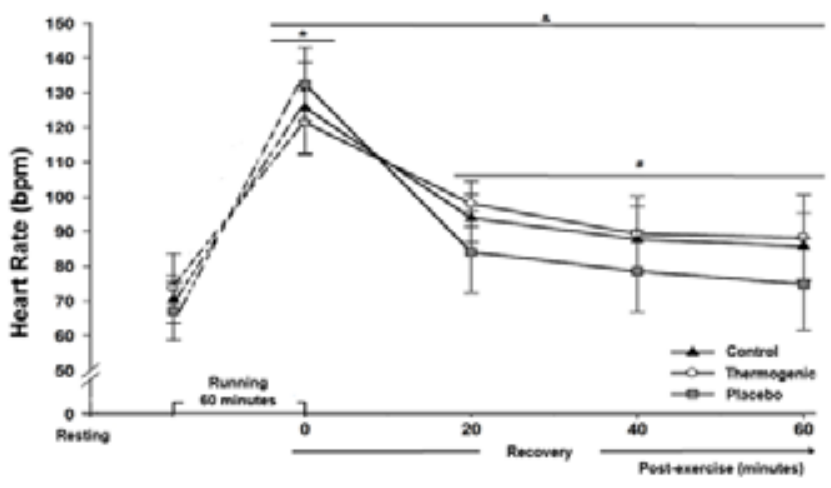

Source: Research data.

$\mathrm{HR}^{*}$ significant difference between 0 min and resting in placebo, control, and thermogenic groups $(p<0.05)$; \# significant differences at 20 -min post-exercise intervals $(20,40$, and $60 \mathrm{~min}$ ) compared to $0 \mathrm{~min}$ in all groups ( $p$ $<0,05)$. \& significant difference between $0 \mathrm{~min}$ and at 20 -min post-exercise intervals $(20,40$, and $60 \mathrm{~min})$ compared to resting.

Thermogenic supplementation did not abolish PEH compared to PE and CE groups. However, it was observed that the supplement suppresses SBP reduction. There was no interaction between the factors group $x$ time in the SBP analysis ( $p=0.16, \dot{\omega}=0.22$ ). There was also no effect for the group factor $(p=0.24$, $\dot{\omega}=0.12$ ), but there was an effect for the moment factor $(p<0.01, \dot{\omega}=1.00)$ in which the means of the groups (125.14 \pm 2.10$)$ was significantly lower at $0 \mathrm{~min}$ $(135.03 \pm 2.10, p<0.01, d=4.71)$, and higher at 20 $\min (119.37 \pm 2.10, \mathrm{p}<0.01, d=2.75), 40 \min (116.79$ $\pm 2.43, \mathrm{p}<0.01, d=3.68)$, and $60 \mathrm{~min}(115.96 \pm 2.10$, $\mathrm{p}<0.01, d=4,37)$.
Figure 4 - Behavior of the systolic blood pressure before and during the 60-min of post exercise recovery. Data presented as means and standard deviation of the means

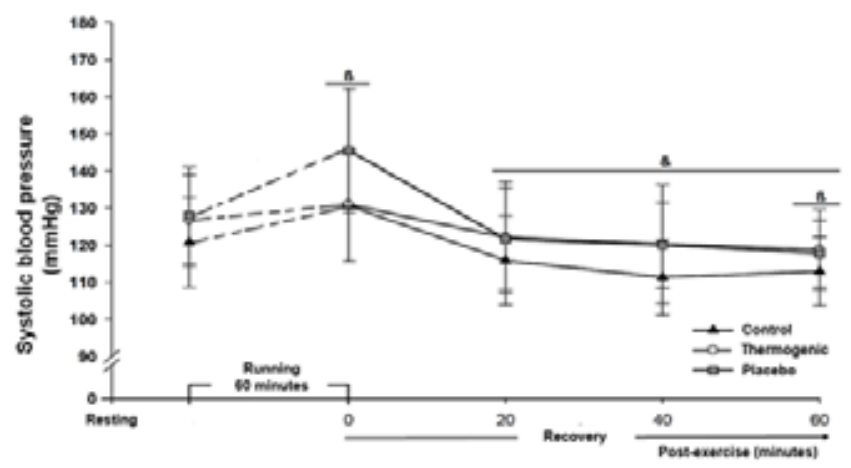

Source: Research data.

* $\beta$ significant difference to 0 min and moment post exercise at 60-min intervals compared to resting. \& significant difference to moment post exercise at 20-min intervals (20,40, and $60 \mathrm{~min})$ compared to immediately post exercise.

There was no interaction between the factors (group vs. moment) in the DBP analysis ( $p=0.84, \dot{\omega}=$ $0.29)$. There was also no effect for the group factor $(p$ $=0.97, \dot{\omega}=0.10)$, but there was an effect for the moment factor $(p<0.01, \dot{\omega}=0.98)$ in which the means of the groups $(72.00 \pm 1.44)$ was significantly lower at 0 $\min (78.14 \pm 1.44, p<0.01, d=4,26)$, and higher at 20 $\min (72.59 \pm 1.44, p<0.01, d=0.41), 40 \min (75.40 \pm$ $15.92, \mathrm{p}<0.01, d=0,39)$, and $60 \min (70.22 \pm 1.44, p$ $<0.01, d=1,24)$. 
Figure 5 - Behavior of the diastolic blood pressure before and during the 60-minute recovery. Data presented as means and standard deviation of the means

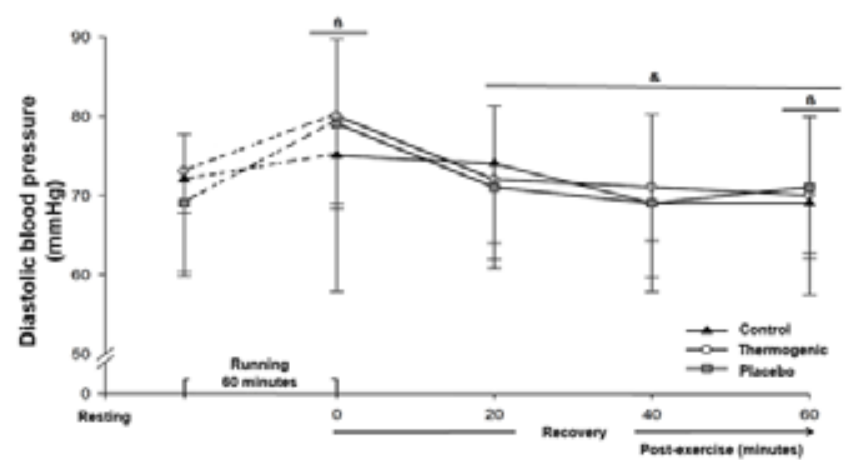

Thermogenic supplementation did not abolish

$\mathrm{DBP} * \beta$ significant difference at $0 \mathrm{~min}$ and $60 \mathrm{~min}$ compared to resting. ( $p<0.05) ; \&$ significant difference between 20 -min post-exercise intervals $(20,40$, and $60 \mathrm{~min})$ and $0 \mathrm{~min}$.

\section{DISCUSSION}

The present study demonstrated that the use of the thermogenic supplement based on caffeine, theobromine, p-synephrine, yohimbine $\mathrm{HCL}$, and rauwolscine was not able to significantly alter the 1-hour PEH in healthy young men. However, thermogenic supplementation increased the blood pressure in $>5 \mathrm{mmHg}$ compared to the placebo and control groups. The reduction of $>5 \mathrm{mmHg}$ is reportedly associated with $>34 \%$ less stroke risk and $>21 \%$ less coronary heart diseases (MACMAHON et al., 1990).

Magalhães (2013) investigated the effect of a single dose of the Nutrex Lipo-6 Black $^{\circledR}$ in young subjects in a 30-minute resting state, immediately after an aerobic exercise session and $30 \mathrm{~min}$ post-exercise. There were no significant differences between supplemented and placebo groups in resting measures and after 30 minutes of a 40-minute moderate aerobic session. This result is presumably due to the low dosage of the supplement ingested: two capsules containing mainly synephrine $(20 \mathrm{mg})$, yohimbine $(4 \mathrm{mg})$, caffeine $(200 \mathrm{mg})$, phenylethylamine $(120 \mathrm{mg})$, diiodothyronine $(100 \mathrm{mcg})$, and other substances. The main differences compared to our study was the dosage (3 capsules) used and the time of supplement administration (24h).

Moreover, Jitomir et al. (2008) analyzed the effect of a thermogenic containing the same active ingredients as ours. They compared 3 capsules of a thermogenic supplement containing anhydrous caffeine (317 mg), mate herb extract, synephrine HCL (20 mg), yohimbine and yohimbine $\mathrm{HCL}(9 \mathrm{mg})$, and other ingredients. The placebo group ingested a capsule containing cellulose $(500 \mathrm{mg})$, after 60 minutes of inges- tion and 60 minutes after an aerobic exercise session using an incremental protocol. Similar, they reported no significant differences in HR, SBP, and DBP at moments before, during, and after the exercise for the supplement and placebo groups.

However, Haller et al. (2008) reported an increase in DBP after a 30-minutes cycle ergometer session at $75-80 \%$ HRmax after the use of a thermogenic supplement containing synephrine $(21 \mathrm{mg})$ and caffeine $(304 \mathrm{mg})$ in adults. It is possible that the moderate duration and the type of exercise (cycle ergometer) did not significantly alter the absorption of synephrine and caffeine, causing this increase in DBP differently from our long-duration exercise study.

The effects of synephrine, an ingredient present in several thermogenic supplements, is controversial. When investigated in combination with caffeine, some studies show that it causes an increase in $\mathrm{HR}$ and PA (BENT; PADULA; NEUHAUS, 2004; PENZAK et al., 2001). However, when we investigated supplements containing synephrine, caffeine, and other ingredients, no increase in HR and PA was observed (HALLER; BENOWITZ; JACOB, 2005), which reinforces our findings.

It has been reported that supplements containing yohimbine, another thermogenic component used in our study, is related to adverse effects such as increased SBP, DBP, and HR after supplementation at rest (SWANN et al., 2013), as well as increased panic symptoms respectively (VASA et al., 2009). They reported changes in hemodynamic variables in healthy youngsters after $0.4 \mathrm{mg} / \mathrm{kg}$ dosages. Moreover, Hoffman et al. (2009) observed a significant increase in HR and SBP, but no change in DBP. On the other hand, Wilborn et al. (2009) and Jitomir et al. (2008) stated that the supplementation containing yohimbine did not cause an increase in $\mathrm{HR}$ and $\mathrm{BP}$.

A study observed blood pressure elevation caused by caffeine in subjects prone to hypertension (NOORDZIJ et al., 2005). This effect is corroborated by studies that evaluated PEH after caffeine use in the respective populations, in which caffeine had adverse effects on hemodynamic variables (SOUZA et al., 2016). However, similarly to our investigation, the same result was not found in a study with healthy youngsters when they underwent the ingestion of caffeine (FERNÁNDEZ-ELÍAS et al., 2015).

Mitchell et al. (2011) found that the consumption of theobromine, also present in the Lipo- 6 Black Ultra Concentre Nutrex ${ }^{\circledR}$, in combination with caffeine increased SBP, DBP, and HR at rest when compared to the group that ingested only the caffeine. This effect is presumably due to its vasodilatory properties, which 
theoretically would explain the control of $H R$ and $B P$, and probably the non-attenuation of SBP immediately after exercise.

Rauwolscine, also known as $\alpha$-yohimbine, is an alkaloid found in the same plant from which yohimbine is extracted, and it acts as an adrenergic blocking agent (LUCAS; NEAL-KABABICK; ZWEIGENBAUM, 2015). To the best of our knowledge, there are no studies in the literature evaluating the effects of this ingredient alone or with other ingredients in hemodynamic variables. Only one study with dogs found a vasodilator effect and an adrenergic blockade, but no significant changes in HR were found (LEVY; KOELLE, 1958).

The effects of acute thermogenic supplementation on PEH are controversial. Tinsley et al. (2017) compared the chronic effects of two supplements over six weeks, in combination with a resistance training program. One group ingested a thermogenic containing Green Tea, Anhydrous Caffeine, Ginseng, $\mathrm{N}$-Acetyl-L-Tyrosine, 4: 1 Maca (Lepidium meyenii) Root Extract, Alpha Lipoic Acid and other ingredients. The other group ingested a maltodextrin-containing placebo. There were no differences in resting $H R$ and BP between both groups.

The main limitation of our study is that we investigated only the acute effect of thermogenic supplementation. Thus, we were unable to detect significant changes in the PEH during the exercise session. Moreover, the sample consisted of healthy volunteers only, and therefore, the results cannot be extended to people with health problems. Further investigation, with longitudinal and crossover designs, should assess the effect of the long-term use of thermogenics on the post-exercise hemodynamic response, as well as in other populations

\section{CONCLUSION}

This study aimed to verify the effects of thermogenic supplements on post aerobic exercise session hemodynamic responses. We demonstrated that there was an increase of $>5 \mathrm{mmHg}$ on post-exercise blood pressure after 3 dosages of thermogenic supplements ingestion, which can increase the risk of cardiovascular diseases, such as hypertension and stroke. Based on the results of the present investigation, the intake of thermogenic supplements may abolish the PEH response in healthy young people. Our results reinforce the need for further studies on a larger population and with chronic administration of thermogenic supplements in order to better clarify the hemodynamic effects of this supplement.

\section{REFERENCES}

ADER, J. L. et al. Fisiologia. 1. ed. Rio de Janeiro: Guanabara Koogan, 2005.

ANUNCIAÇÃO, P. G.; POLITO, M. D. A review on post-exercise hypotension in hypertensive individuals. Arquivos Brasileiros de Cardiologia, v. 96, p. e100-e109, 2011.

BENT, S.; PADULA, A.; NEUHAUS, J. Safety and efficacy of citrus aurantium for weight loss. The American Journal of Cardiology, v. 94, n. 10, p. 1.359-1.361, 2004.

BRAZILIAN SOCIETY OF CARDIOLOGY; BRAZILIAN SOCIETY OF HYPERTENSION; BRAZILIAN SOCIETY OF NEPHROLOGY. VI Brazilian Guidelines on Hypertension. Rev Bras Hypertens, p. 69, 2010.

BRUM, P. C. et al. Adaptações agudas e crônicas do exercício físico no sistema cardiovascular. Rev Paul Educ Fís, v. 18, n. ago, n. esp., p. 21-31, 2004.

CAMPBELL, B. I. et al. The effects of a fat loss supplement on resting metabolic rate and hemodynamic variables in resistance trained males: a randomized, double-blind, placebo-controlled, cross-over trial. Journal of the International Society of Sports Nutrition, v. 13, n. 1, 2016.

COHEN, J. Statistical Power Analysis for the Behavioral Sciences. $2^{\text {nd }}$ ed. Hillsdale: Routledge, 1988.

CRIVELIN, V. et al. Suplementos alimentares: perfil do consumidor e composição química. Revista Brasileira de Nutriçao Esportiva, v. 12, n. 69, p. 30-36, 2018.

CUCKSON, A. C. et al. Validation of the Microlife BP 3BTO-A oscillometric blood pressure monitoring device according to a modified British Hypertension Society protocol. Blood Pressure Monitoring, v. 7, n. 6, p. 319-324, 2002.

DICKINSON, A. et al. Consumer Usage and Reasons for Using Dietary Supplements: Report of a Series of Surveys. Journal of the American College of Nutrition, v. 33, n. 2, p. 176-182, 4 mar. 2014.

FERNÁNDEZ-ELÍAS, V. E. et al. Ingestion of a moderately high caffeine dose before exercise increases postexercise energy expenditure. International Journal of Sport Nutrition and Exercise Metabolism, v. 25, n. 1, p. 46-53, 2015.

GOMES, C. et al. Uso de suplementos termogênicos à base de cafeína e fatores associados à qualidade de vida relacionada à saúde em praticantes de atividade física. Revista Brasileira de Prescrição e Fisiologia do Exercício, v. 8, n. 49, p. 695-704, 2014.

HALLER, C. A. et al. Human pharmacology of a performance-enhancing dietary supplement under resting and exercise conditions. British Journal of Clinical Pharmacology, v. 65, n. 6, p. 833-840, 2008.

HALLER, C. A.; BENOWITZ, N. L.; JACOB, P. Hemodynamic effects of ephedra-free weight-loss supplements in humans. The American Journal of Medicine, v. 118, n. 9, p. 9981.003, 2005. 
HOFFMAN, J. R. et al. Thermogenic effect of an acute ingestion of a weight loss supplement. Journal of the International Society of Sports Nutrition, v. 6, n. 1, 2009.

JITOMIR, J. et al. The acute effects of the thermogenic supplement Meltdown on energy expenditure, fat oxidation, and hemodynamic responses in young, healthy males. Journal of the International Society of Sports Nutrition, v. 5, n. 1, p. 23, 2008.

KARVONEN, M. J.; KENTALA, E.; MUSTALA, O. The effects of training on heart rate; a longitudinal study. Ann Med Exp Biol Fenn, v. 35, n. 3, p. 307-315, 1957.

LAKENS, D. Calculating and reporting effect sizes to facilitate cumulative science: A practical primer for t-tests and ANOVAs. Frontiers in Psychology, v. 4, n. 863, 2013.

LEVY, B.; KOELLE, G. B. The Cardiovascular and Respiratory Actions of Rauwolscine. Journal of Pharmacology and Experimental Therapeutics, v. 123, n. 4, 1958.

LUCAS, D.; NEAL-KABABICK, J.; ZWEIGENBAUM, J. Characterization and Quantitation of Yohimbine and Its Analogs in Botanicals and Dietary Supplements Using LC/QTOF-MS and LC/QQQ-MS for Determination of the Presence of Bark Extract and Yohimbine Adulteration. Journal of AOAC International, v. 98, n. 2, p. 330-335, 2015.

MACMAHON, S. et al. Blood pressure, stroke, and coronary heart disease. Part 1, prolonged differences in blood pressure: prospective observational studies corrected for the regression dilution bias. The Lancet, v. 335, n. 8.692, p. 765774, 1990.

MAGALHÃES, L. M. et al. Single dose of dietary supplement Nutrex Lipo-6 Black $^{\circledR}$ limits the post exercise hypotension induced by aerobic exercise in young adults. Journal of Pharmacy and Nutrition Sciences, v. 3, n. 2, p. 127-133, 2013.

MITCHELL, E. S. et al. Differential contributions of theobromine and caffeine on mood, psychomotor performance and blood pressure. Physiology \& Behavior, v. 104, n. 5, p. 816822, 2011.

MUND, R. A.; FRISHMAN, W. H. Brown Adipose Tissue Thermogenesis. Cardiology in Review, v. 21, n. 6, p. 265-269, 2013.

NOORDZIJ, M. et al. Blood pressure response to chronic intake of coffee and caffeine: a meta-analysis of randomized controlled trials. Journal of Hypertension, v. 23, n. 5, p. 921928, 2005.

OUTLAW, J. J. et al. Acute effects of a commercially-available pre-workout supplement on markers of training: a double-blind study. Journal of the International Society of Sports Nutrition, v. 11, n. 1, 2014.

PENZAK, S. R. et al. Seville (sour) Orange Juice: Synephrine Content and Cardiovascular Effects in Normotensive Adults. The Journal of Clinical Pharmacology, v. 41, n. 10, p. 1.0591.063, 2001.

RODRIGUES-JUNIOR, J. F. C. et al. Androgenic-anabolic steroids inhibited post-exercise hypotension: a case control study. Brazilian Journal of Physical Therapy, v. 22, n. 1, p. 1-5, 2017.
SOUZA, A. A. et al. Influence of different doses of coffee on post-exercise blood pressure response. American Journal of Cardiovascular Disease, v. 6, n. 4, p. 146-152, 2016.

SWANN, A. C. et al. Norepinephrine and impulsivity: effects of acute yohimbine. Psychopharmacology, v. 229, n. 1, p. 83-94, 2013.

TEIXEIRA, L. et al. Post-concurrent exercise hemodynamics and cardiac autonomic modulation. European Journal of Applied Physiology, v. 111, n. 9, p. 2.069-2.078, 2011.

TINSLEY, G. M. et al. Influence of a thermogenic dietary supplement on safety markers, body composition, energy expenditure, muscular performance and hormone concentrations: A randomized, placebo-controlled, double-blind trial. Journal of Sports Science and Medicine, v. 16, n. 4, p. 459-467, 2017.

VASA, R. A. et al. Effects of yohimbine and hydrocortisone on panic symptoms, autonomic responses, and attention to threat in healthy adults. Psychopharmacology, v. 204, n. 3, p. 445-455, 2009.

WILBORN, C. et al. Effects of ingesting a commercial thermogenic product on hemodynamic function and energy expenditure at rest in males and females. Applied Physiology, Nutrition, and Metabolism, v. 34, n. 6, p. 1.073-1.078, 2009. 